\title{
PENYULUHAN KESEHATAN UNTUK MENINGKATKAN PEMAHAMAN KADER TENTANG PENANGANAN STUNTING PADA BALITA
}

\author{
Agusta Saraswati $^{1}$, Suharmanto $^{2}$, Bayu Anggileo Pramesona ${ }^{2}$, Susianti $^{2}$ \\ ${ }^{1}$ Mahasiswa Program Studi Magister Kesehatan Masyarakat Fakultas Kedokteran \\ Universitas Lampung \\ ${ }^{2}$ Dosen Program Studi Magister Kesehatan Masyarakat Fakultas Kedokteran \\ Universitas Lampung
}

Email:agustasaraswati1108@gmail.com,suharmanto@fk.unila.ac.id

${ }^{2}$ Penulis korespondensi

\begin{abstract}
Stunting is a condition characterized when a child's length or height is less than his age. The number of stunting cases in Indonesia in 2013 reached 37.8\%, while in 2019 it decreased to 27.67\%. There were 11 toddlers stunting at the Karang Anyar Public Health Center. The purpose of this activity is to increase the understanding of cadres about handling stunting in toddlers. This activity is one of the efforts to reduce the incidence of stunting in toddlers. The target of this activity is a cadre of 16 people. The activity will be held on October 1, 2021 at 08.00-12.00 in the Karang Anyar Health Center Hall, South Lampung. The method used in this activity consists of providing material by experts and discussion. The evaluation carried out to assess the success of this activity consists of an initial evaluation, process evaluation and final evaluation. Before being given the material, a pre-test was conducted (mean value 6.5) and after the material was given a post-test (mean value 8.7). The results before and after were compared to measure the understanding of cadres about the handling of stunting in toddlers. The community service team involved are lecturers and students in the Master of Public Health Study Program. The result of this activity is an increase in the understanding of the cadres about the handling of stunting in toddlers. Suggestions that can be given to Public Health Center are to create programs that can maintain and increase cadres' understanding of stunting management, such as health education and health seminars.
\end{abstract}

Keywords: toddlers; cadres; understanding; stunting handling; health education

\begin{abstract}
Abstrak
Stunting adalah kondisi yang ditandai ketika panjang atau tinggi badan anak kurang jika dibandingkan dengan umurnya. Jumlah kasus stunting di Indonesia pada tahun 2013 mencapai 37,8\% sedangkan tahun 2019 menurun menjadi 27,67\%. Stunting di Puskesmas Karang Anyar sebanyak 11 balita. Tujuan kegiatan ini adalah meningkatkan pemahaman kader tentang penanganan stunting pada balita. Kegiatan ini merupakan salah satu upaya untuk menurunkan angka kejadian stunting pada balita. Sasaran kegiatan ini adalah kader berjumlah 16 orang. Kegiatan dilaksanakan pada tanggal 1 Oktober 2021 pukul 08.00-12.00 WIB di Aula Puskesmas Karang Anyar Lampung Selatan. Metode yang digunakan dalam kegiatan ini terdiri dari pemberian materi oleh pakar dan diskusi. Evaluasi yang dilakukan untuk menilai keberhasilan kegiatan ini terdiri dari evaluasi awal, evaluasi proses dan evaluasi akhir. Sebelum diberikan materi, dilakukan pre-test (nilai rata-rata 6,5) dan setelah materi diberikan post-test (nilai rata-rata 8,7). Hasil sebelum dan sesudah dibandingkan untuk mengukur pemahaman kader tentang penanganan stunting pada balita. Tim pengabdian masyarakat yang dilibatkan adalah dosen dan mahasiswa pada Program Studi Magister Kesehatan Masyarakat. Hasil kegiatan ini adalah meningkatnya pemahaman para kader tentang
\end{abstract}


penanganan stunting pada balita. Saran yang dapat diberikan bagi Puskesmas adalah membuat program yang dapat mempertahankan dan meningkatkan pemahaman kader tentang penanganan stunting seperti penyuluhan kesehatan dan seminar kesehatan.

Kata kunci: balita; kader; pemahaman; penanganan stunting; penyuluhan kesehatan

Korespondensi: Dr. Suharmanto, S.Kep., MKM, alamat Jl. Soemantri Brodjonegoro No. 1, HP 089632832380, e-mail suharmanto@fk.unila.ac.id

\section{PENDAHULUAN}

Stunting adalah kekurangan gizi pada bayi di 1000 hari pertama kehidupan yang berlangsung lama dan menyebabkan terhambatnya perkembangan otak dan tumbuh kembang anak (Sari \& Oktacia, 2018). Karena mengalami kekurangan gizi menahun, bayi stunting tumbuh lebih pendek dari standar tinggi balita seumurnya (Akombi et al., 2017). Masalah stunting penting untuk diselesaikan, karena berpotensi mengganggu potensi sumber daya manusia dan berhubungan dengan tingkat kesehatan, bahkan kematian anak (Roediger et al., 2020). Hasil dari Survei Status Gizi Balita Indonesia (SSGBI) menunjukkan bahwa terjadi penurunan angka stunting berada pada $27,67 \%$ pada tahun 2019.

Stunting disebabkan berbagai faktor kekurangan gizi pada bayi (Ika \& Ariati, 2019). Stunting itu adalah produk yang dihasilkan dari kehamilan (Fajriani et al., 2020). Hal lain yang menyebabkan stunting adalah bayi terlahir dengan gizi kurang yang diukur melalui ukuran panjang tubuh tidak sampai 48 sentimeter dan berat badannya tidak sampai 2,5 kilogram (Dewey, 2016). Tidak hanya itu, tingginya angka stunting di Indonesia juga ditambah dari bayi yang terlahir normal akan tetapi tumbuh dengan kekurangan asupan gizi sehingga menjadi stunting (Kusumawati et al., 2013). Satu hal yang harus di pahami bersama adalah stunting itu bisa diatasi untuk tidak menjadi stunting atau dikoreksi itu diseribu hari kehidupan pertama (Danaei et al., 2016). Sehingga ketika bayi lahir sampai 2 tahun ini masih bisa dilakukan modifikasi, intervensi supaya tidak bisa menjadi stunting (Cahyani et al., 2019).

Dalam mengatasi stunting, dapat dimanfaatkan tenaga kader yang nantinya akan membantu menjalankan pendampingan kepada keluarga dan calon pasangan usia subur sebelum proses kehamilan. Selain tetap mengoptimalkan pelayanan melalui kader posyandu, juga harus dilakukan penanganan dari hulu ke hilir. Dimulai dari sebelum anak lahir, yakni saat para ibu atau pasangan usia subur merencanakan akan menikah, mereka harus dicek kesehatannya. Banyak perempuan Indonesia yang hamil dalam kondisi yang sebenarnya belum siap sehingga kemungkinan anaknya bisa stunting (Mugianti et al., 2018).

Masalah stunting masih terjadi di Desa Karang Anyar Kecamatan Jati Agung Lampung Selatan. Berdasarkan wawancara pada 10 ibu hamil, 
didapatkan bahwa 7 orang $(70 \%)$ mengatakan tidak tahu tentang stunting dan cara pencegahannya. Sedangkan 3 orang $(30 \%)$ mengatakan pernah mendengar istilah stunting tetapi belum tahu secara detail. Wawancara pada 10 orang kader, didapatkan 8 orang (80\%), mengatakan sudah mengetahui tentang stunting, tetapi mereka mengatakan perlu membaca lagi untuk materi stunting untuk menguatkan pemahaman tentang pencegahan stunting. Berdasarkan uraian latar belakang masalah tersebut, perlu dilakukan kegiatan "Penyuluhan Kesehatan Untuk Meningkatkan Pemahaman Tentang Penanganan Stunting Pada Balita di Desa Karang Anyar Kecamatan Jati Agung Lampung Selatan tahun 2021”. Tujuan kegiatan ini adalah meningkatkan pemahaman kader tentang penanganan stunting pada balita. Kegiatan ini merupakan salah satu upaya untuk menurunkan angka kejadian stunting pada balita.

\section{TINJAUAN LITERATUR}

Metode kegiatan ini meliputi persiapan, pelaksanaan dan evaluasi. Pada tahap persiapan meliputi. Penyuluhan kesehatan merupakan kegiatan penambahan pengetahuan yang diperutukkan bagi masyarakat melalui penyebaran pesan. Tujuan kegiatan penyuluhan kesehatan yaitu untuk mencapai tujuan hidup sehat dengan cara mempengaruhi prilaku masyarakat baik itu secara individu ataupun kelompok dengan menyampaian pesan. Penyuluhan kesehatan merupakan gabungan dari berbagai kegiatan dan kesempatan yang berlandaskan prinsip- prinsip belajar sehingga harapannya dengan adanya penyuluhan kesehatan dapat membuat masyarakat lebih sadar akan pentingnya pola kehidupan yang sehat. Sasaran penyuluhan kesehatan yaitu mencakup individu, keluarga, kelompok dan masyarakat. Penyuluhan kesehatan pada individu biasanya dilakukan di rumah sakit, klinik, puskesmas, posyandu, keluarga binaan dan masyarakat binaan. Materi atau pesan yang disampaikan dalam penyuluhan kesehatan biasanya disesuaikan dengan kebutuhan kesehatan individu, keluarga, kelompok dan masyarakat. Sehingga materi atau pesan dapat dirasakan langsung manfaatnya. Untuk menyampaikan pesan atau materi penyuluhan kesehatan biasanya bahasa yang digunakan ialah bahasa yang mudah dimengerti sehingga tidak terlalu sulit untuk dimengerti oleh sasaran atau objek penyuluhan kesehatan. Media merupakan salah satu sarana yang penting dalam penyuluhan kesehatan. Media yang biasanya digunakan dalam penyuluhan kesehatan seperti media cetak, media elektronik, dan media luar ruang.

Tujuan penyuluhan kesehatan antara lain tercapainya perubahan perilaku individu, keluarga dan masyarakat dalam membina dan memelihara perilaku sehat dan lingkungan sehat, serta berperan aktif dalam mewujudkan derajat kesehatan yang optimal; terbentuknya perilaku sehat pada individu, keluarga, kelompok dan masyarakat yang sesuai dengan konsep hidup sehat baik fisik, mental dan sosial sehingga dapat menurunkan angka kesakitan dan kematian; merubah 
perilaku perseorangan dan atau masyarakat dalam bidang kesehatan.

\section{METODE PELAKSANAAN}

Metode kegiatan ini meliputi persiapan, pelaksanaan dan evaluasi. Pada tahap persiapan meliputi koordinasi tempat dilakukan penyuluhan, persiapan alat dan bahan untuk kegiatan penyuluhan serta pembagian job desc personalia. Sebelum kegiatan pengabdian kepada masyarakat dilaksanakan tentunya akan dilakukan proses perizinan ke pemerintah setempat terlebih dahulu. Pada tahap pelaksanaan meliputi pemberian materi dan dilanjutkan diskusi. Pada tahap evaluasi dilakukan untuk menilai keberhasilan kegiatan ini terdiri dari evaluasi awal, evaluasi proses dan evaluasi akhir. Evaluasi awal dilakukan dengan memberikan pre-test kepada peserta yang berisi pertanyaan-pertanyaan yang terkait dengan materi yang akan diberikan. Hasil dari evaluasi ini berupa nilai skor tiap peserta, yang merupakan hasil pembagian dari jawaban benar dengan total jumlah pertanyaan dikalikan 100. Evaluasi proses dilakukan dengan melihat tanggapan masyarakat melalui pertanyaan-pertanyaan yang diajukan ataupun umpan balik yang diberikan dalam diskusi. Evaluasi akhir dilakukan dengan memberikan post-test kepada peserta yang berisi pertanyaanpertanyaan yang sama yang telah diberikan pada pre-test. Skor nilai posttest dibandingkan dengan skor nilai pretest. Apabila nilai post-test lebih tinggi dari nilai pre-test maka kegiatan penyuluhan yang diberikan berhasil meningkatkan pengetahuan masyarakat.

Kegiatan ini merupakan salah satu upaya untuk menurunkan angka kejadian stunting pada balita. Sasaran kegiatan ini adalah kader berjumlah 16 orang. Kegiatan dilaksanakan pada tanggal 1 Oktober 2021 pukul 08.00-12.00 WIB di Aula Puskesmas Karang Anyar Lampung Selatan. Metode yang digunakan dalam kegiatan ini terdiri dari pemberian materi oleh pakar dan diskusi. Hasil sebelum dan sesudah dibandingkan untuk mengukur pemahaman kader tentang penanganan stunting pada balita. Tim pengabdian masyarakat yang dilibatkan adalah dosen dan mahasiswa pada Program Studi Magister Kesehatan Masyarakat.

\section{HASIL DAN PEMBAHASAN}

Pelaksanaan kegiatan ini pada tanggal 1 Oktober 2021, jam 08.00-12.00 WIB di Aula Puskesmas Karang Anyar Kecamatan Jati Agung Lampung Selatan. Sasaran kegiatan ini adalah 16 orang kader. Bentuk kegiatan ini meliputi pemberian materi tentang stunting dilanjutkan dengan diskusi. Sebelum diberikan materi, peserta diberikan lembar pre-tes, kemudian diberikan materi. Setelah diberikan materi, peserta diberikan lagi lembar post-tes. Lembar pertanyaan berisikan 10 pertanyaan tentang stunting, bentuk pilihan ganda yang meliputi pertanyaan pengertian, penyebab, faktor risiko, dampak, pencegahan dan penanganan stunting. 


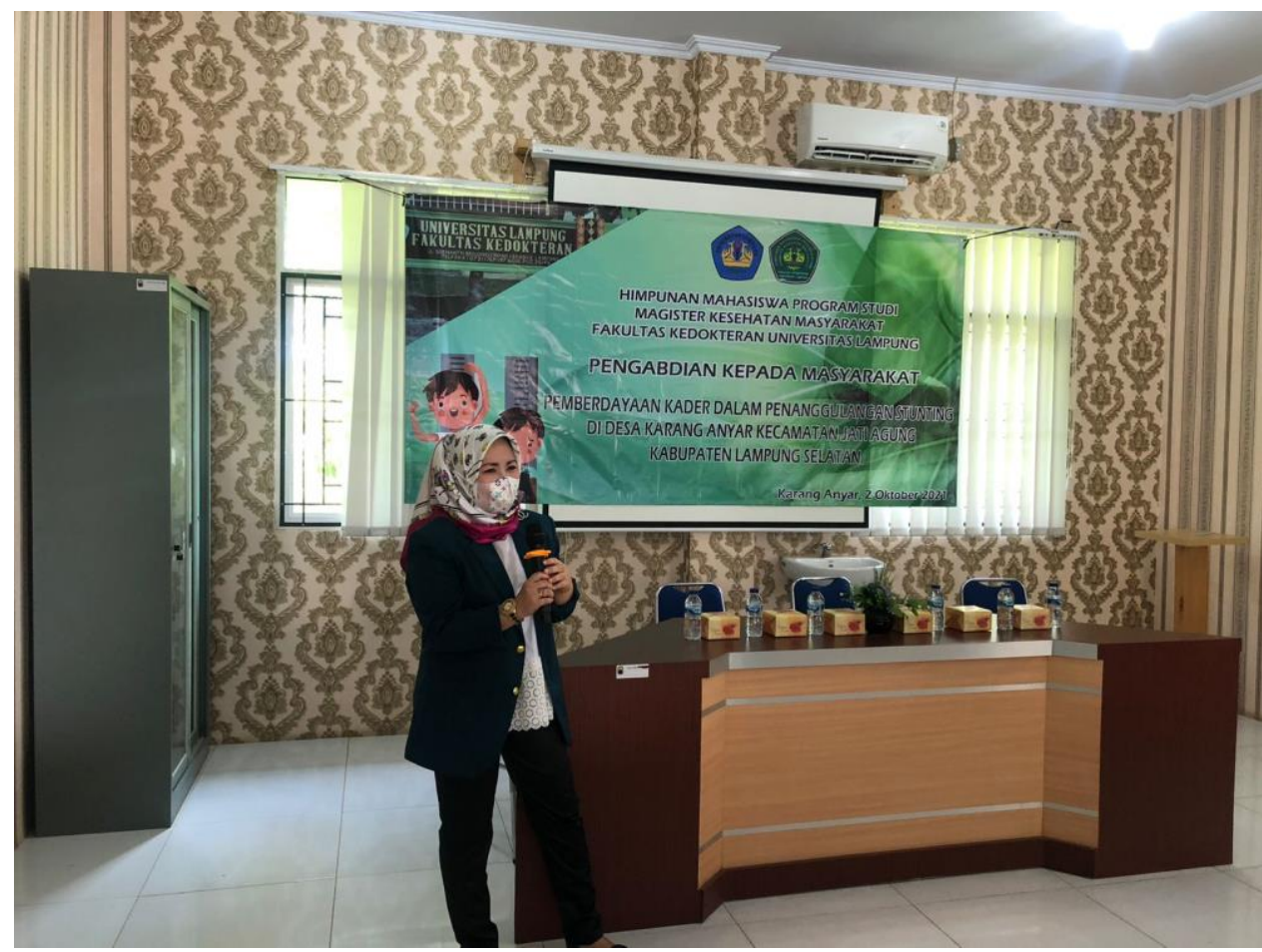

Gambar 1. Pemberian Materi Penanganan Stunting

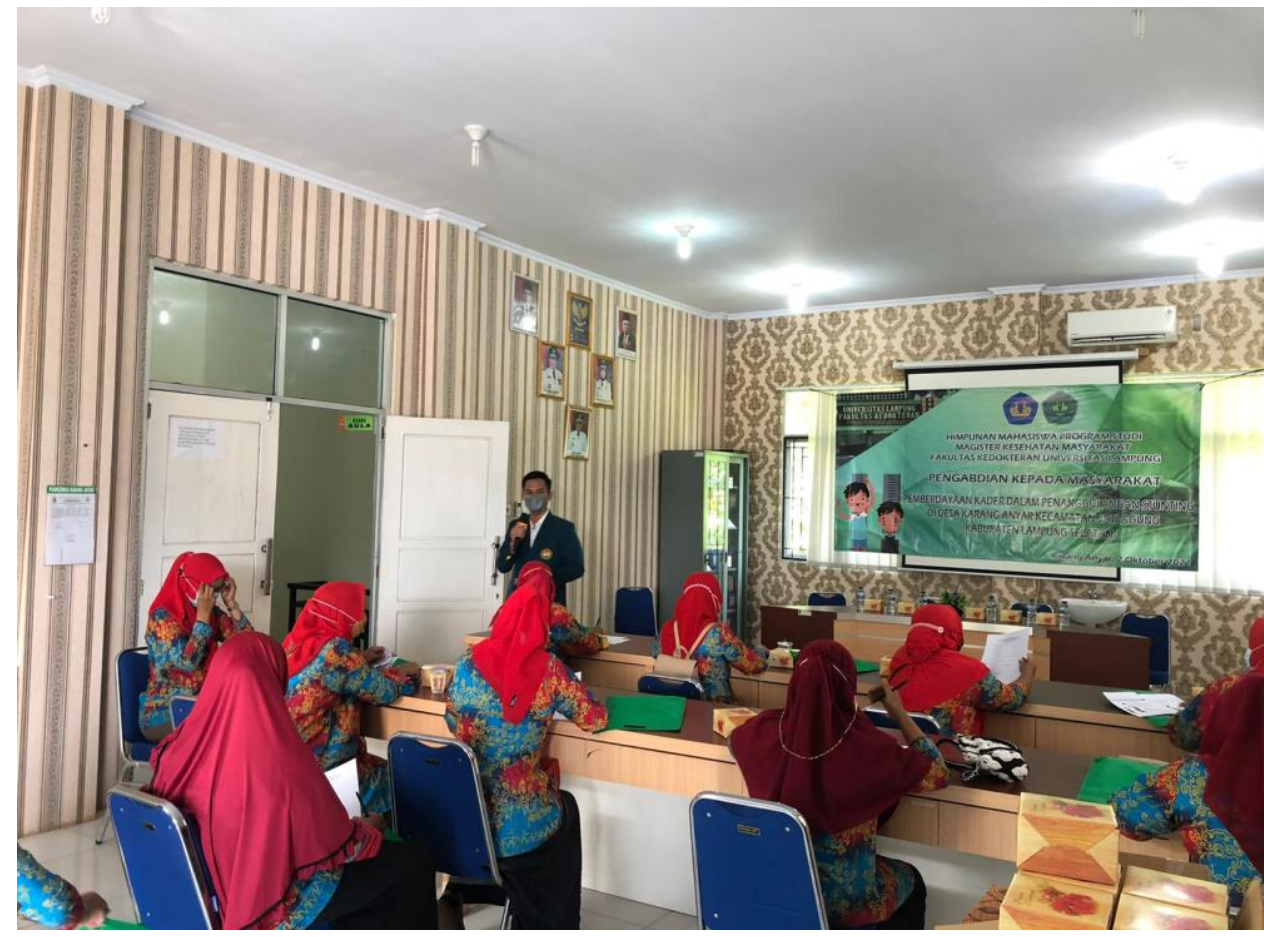

Gambar 2. Peserta Kegiatan Penyuluhan Kesehatan Penanganan Stunting

Hasil dari pre-tes dan post-tes dibandingkan untuk mengetahui peningkatan pemahaman kader tentang stunting dan pencegahannya. Hasil pengukuran disajikan dalam tabel berikut: 
Tabel 1. Hasil Pengukuran Pemahaman Tentang Penanganan Stunting

Kader Nilai Kategori Nilai Kategori Peningkatan

\begin{tabular}{|c|c|c|c|c|c|}
\hline & Pre-Tes & - -10008 & Post-Tes & 年 & Skor \\
\hline \multirow[t]{2}{*}{1} & & Kurang & & Baik & \\
\hline & 3 & Baik & 8 & & 5 \\
\hline \multirow[t]{2}{*}{2} & & Kurang & & Baik & \\
\hline & 4 & Baik & 7 & & 3 \\
\hline \multirow[t]{2}{*}{3} & & Kurang & & Baik & \\
\hline & 3 & Baik & 6 & & 3 \\
\hline \multirow[t]{2}{*}{4} & & Kurang & & Baik & \\
\hline & 5 & Baik & 7 & & 2 \\
\hline 5 & 6 & Baik & 8 & Baik & 2 \\
\hline \multirow[t]{2}{*}{6} & & Kurang & & Baik & \\
\hline & 2 & Baik & 7 & & 5 \\
\hline \multirow[t]{2}{*}{7} & & Kurang & & Baik & \\
\hline & 3 & Baik & 8 & & 5 \\
\hline \multirow[t]{2}{*}{8} & & Kurang & & Baik & \\
\hline & 4 & Baik & 6 & & 2 \\
\hline 9 & 7 & Baik & 8 & Baik & 1 \\
\hline \multirow[t]{2}{*}{10} & & Kurang & & Baik & \\
\hline & 5 & Baik & 8 & & 3 \\
\hline \multirow[t]{2}{*}{11} & & Kurang & & Baik & \\
\hline & 4 & Baik & 7 & & 3 \\
\hline \multirow[t]{2}{*}{12} & & Kurang & & Baik & \\
\hline & 5 & Baik & 8 & & 3 \\
\hline 13 & 6 & Baik & 8 & Baik & 2 \\
\hline 14 & 6 & Baik & 8 & Baik & 2 \\
\hline \multirow[t]{2}{*}{15} & & Kurang & & Baik & \\
\hline & 5 & Baik & 7 & & 2 \\
\hline 16 & 7 & Baik & 8 & Baik & 1 \\
\hline
\end{tabular}

Hasil pengukuran sebelum diberikan materi pada kader didapatkan bahwa sebanyak 11 orang $(68,75 \%)$ dalam kategori pengetahuan kurang baik karena jawaban benar $\leq 5$ pertanyaan, sedangkan 5 orang $(31,25 \%)$ dalam kategori pengetahuan baik karena jawaban benar $>5$ pertanyaan. Hasil pengukuran sesudah diberikan materi pada kader didapatkan bahwa sebanyak
16 orang $(100 \%)$ dalam kategori pengetahuan baik karena jawaban benar $>5$ pertanyaan.

\section{DISKUSI}

Hasil kegiatan ini menunjukkan adanya peningkatan pemahaman para kader tentang penanganan stunting pada balita. Menurut Permenkes RI No.25 Tahun 2014, kader adalah setiap orang yang dipilih oleh masyarakat dan dilatih 
untuk menangani masalah-masalah kesehatan perorangan atau masyarakat serta bekerja dalam hubungan yang amat dekat dengan tempat-tempat pemberian pelayanan kesehatan. Kader kesehatan adalah anggota masyarakat yang dipilih dari dan oleh masyarakat yang mau dan mampu bekerja sama dalam berbagai kegiatan kemasyarakatan secara sukarela (Sewa et al., 2019).

Kader kesehatan mempunyai peran serta yang besar dalam upaya meningkatkan kemampuan masyarakat menolong dirinya untuk mencapai derajat kesehatan yang optimal dan membina masyarakat dalam bidang kesehatan. Secara teknis, tugas kader yang terkait degan stunting adalah melakukan pendataan balita, melakukan penimbangan serta mencatatnya dalam Kartu Menuju Sehat (KMS), memberikan makanan tambahan, mendistribusikan vitamin A, melakukan penyuluhan gizi serta kunjungan ke rumah ibu yang menyusui dan ibu yang memiliki balita (Parisudha et al., 2020).

Kader kesehatan berperan dalam penanganan stunting. Balita pendek (stunting) adalah kondisi gagal tumbuh pada anak balita akibat kekurangan gizi kronis terutama pada 1.000 Hari Pertama Kehidupan (HPK). Hal ini merupakan status gizi yang didasarkan pada indeks $\mathrm{PB} / \mathrm{U}$ atau TB/U dalam standar antropometri penilaian status gizi anak. Hasil pengukuran pada balita pendek (stunted) berada pada rentang ambang batas (Z-Score) <-2SD sampai dengan 3SD. Balita sangat pendek (severely stunted) menunjukkan hasil pengukuran pada rentang <-3SD. Stunting diukur dengan memperhatikan tinggi atau panjang badan, umur, dan jenis kelamin. Kejadian stunting sulit disadari apabila masyarakat memiliki kebiasaan tidak mengukur tinggi atau panjang balita secara rutin. Stunting dapat terjadi mulai janin masih dalam kandungan ibu dan baru terlihat pada saat anak berumur dua tahun (de Onis \& Branca, 2016).

$$
\text { Hasil pengukuran sebelum }
$$
diberikan materi pada kader didapatkan bahwa sebanyak 11 orang $(68,75 \%)$ dalam kategori pengetahuan kurang baik karena jawaban benar $\leq 5$ pertanyaan, sedangkan 5 orang $(31,25 \%)$ dalam kategori pengetahuan baik karena jawaban benar $>5$ pertanyaan. Hasil pengukuran sesudah diberikan materi pada kader didapatkan bahwa sebanyak 16 orang (100\%) dalam kategori pengetahuan baik karena jawaban benar $>5$ pertanyaan.

Pengetahuan adalah hasil dari tahu dan terjadi setelah orang melakukan penginderaan terhadap objek tertentu. Penginderaan terjadi melalui panca indera manusia yaitu indera penglihatan, pendengaran, penciuman, rasa dan raba. Sebagian besar pengetahuan manusia diperoleh melalui mata dan telinga. Menurut Bloom, pengetahuan merupakan domain sangat penting dalam membentuk tindakan seseorang (overt behavior). Perilaku yang didasari oleh pengetahuan lebih langgeng daripada perilaku yang tidak didasari oleh pengetahuan.

Pengetahuan yang berhubungan dengan masalah kesehatan akan mempengaruhi terjadinya gangguan kesehatan pada kelompok tertentu. Dengan memiliki pengetahuan 
khususnya kesehatan, seseorang dapat mengetahui berbagai macam gangguan kesehatan yang pemecahannya. Aspekaspek pengetahuan gizi diantaranya pangan dan kekurangan), pangan / gizi bayi (ASI, MP ASI, umur pemberian, jenis), pangan dan gizi balita, pangan dan gizi ibu hamil, pertumbuhan anak, kesehatan anak serta pengetahuan tentang pengasuhan anak. Kurangnya pengetahuan gizi mengakibatkan berkurangnya kemampuan menerapkan informasi dalam kehidupan sehari-hari dan merupakan salah satu penyebab terjadinya gangguan gizi. Kurangnya pengetahuan dapat diatasi dengan pemberian informasi melalui penyuluhan kesehatan (Wulandari \& Kusumastuti, 2020).

Penyuluhan kesehatan atau pendidikan kesehatan, yaitu suatu kegiatan atau upaya untuk menyampaikan pesan kesehatan kepada masyarakat, kelompok atau individu. Dengan harapan bahwa dengan adanya pesan tersebut atau individu dapat memperoleh pengetahuan tentang kesehatan yang lebih baik. Akhirnya pengetahuan tersebut diharapkan dapat berpengaruh terhadap perilakunya. Dengan kata lain, dengan adanya pendidikan tersebut dapat membawa akibat terhadap perubahan perilaku sasaran (Yuliani et al., 2018).

Penyuluhan kesehatan juga suatu proses, dimana proses tersebut mempunyai masukan (input) dan keluaran (output). Di dalam suatu proses pendidikan kesehatan yang menuju tercapainya tujuan pendidikan yakni perubahan perilaku dipengaruhi oleh banyak faktor. Faktor-faktor yang mempengaruhi suatu proses pendidikan disamping masukannya sendiri juga metode materi atau pesannya, pendidik atau petugas yang melakukannya, dan alat-alat bantu atau alat peraga pendidikan. Agar dicapai suatu hasil optimal, maka faktor-faktor tersebut harus bekerjasama secara harmonis. Hal ini berarti, bahwa untuk masukan (sasaran pendidikan) tertentu, harus menggunakan cara tertentu pula, materi juga harus disesuaikan dengan sasaran, demikian juga alat bantu pendidikan disesuaikan. Untuk sasaran kelompok, metodenya harus berbeda dengan sasaran massa dan sasaran individual. Untuk sasaran massa pun harus berbeda dengan sasaran individual dan sebagainya.

Tujuan penyuluhan kesehatan adalah tercapainya perubahan perilaku individu, keluarga dan masyarakat dalam membina dan memelihara perilaku hidup sehat dan lingkungan sehat, serta berperan aktif dalam upaya mewujudkan derajat kesehatan yang optimal, terbentuknya perilaku sehat pada individu, keluarga, kelompok dan masyarakat yang sesuai dengan konsep hidup sehat baik fisik, mental dan sosial sehingga dapat menurunkan angka kesakitan dan kematian, menurut WHO tujuan penyuluhan kesehatan adalah untuk merubah perilaku perseorangan dan masyarakat dalam bidang kesehatan (Zuraida et al., 2017).

Berdasarkan kegiatan terdahulu, didapatkan bahwa penyuluhan terbukti efektif meningkatkan pemahaman seseorang. Pengabdian masyarakat penyuluhan kesehatan pada kader 
tentang stunting didapatkan meningkatnya pengetahuan dan pemahaman kader posyandu mengenai deteksi dini stunting pada anak balita serta bertambahnya keterampilan kader posyandu dalam melaksanakan deteksi dini status gizi kronik (stunting) pada balita (Yuliani et al., 2018). Penelitian terdahulu mendapatkan bahwa peran kader berpengaruh positif terhadap dukungan keluarga dan motivasi ibu dalam pencegahan stunting (Wulandari \& Kusumastuti, 2020).

\section{PENUTUP}

Hasil pengukuran sebelum diberikan materi pada kader didapatkan bahwa sebanyak $68,75 \%$ dalam kategori pengetahuan kurang baik, sedangkan $31,25 \%$ dalam kategori pengetahuan baik. Hasil pengukuran sesudah diberikan materi pada kader didapatkan bahwa $100 \%$ dalam kategori pengetahuan baik. Saran yang dapat diberikan bagi Puskesmas adalah membuat program yang dapat mempertahankan dan meningkatkan pemahaman kader tentang penanganan stunting seperti penyuluhan kesehatan dan seminar kesehatan. Rekomendasi publikasi di prosiding SNPPM 2021dan Jurnal Sarwahita.

\section{DAFTAR PUSTAKA}

Akombi, B. J., Agho, K. E., Hall, J. J., Merom, D., Astell-Burt, T., \& Renzaho, A. M. N. (2017). Stunting and severe stunting among children under-5 years in Nigeria: A multilevel analysis. BMC Pediatrics, 17(1), 1-16. https://doi.org/10.1186/s12887-

016-0770-z

Cahyani, D., Listyarini, A. D., Tinggi, S., Kesehatan, I., \& Utama, C. (2019). Balita Dengan Kejadian Stunting Di Desa Undaan Kidul. Prosiding HEFA, 11(3), 36-43.

Danaei, G., Andrews, K. G., Sudfeld, C. R., Fink, G., McCoy, D. C., Peet, E., Sania, A., Smith Fawzi, M. C., Ezzati, M., \& Fawzi, W. W. (2016). Risk Factors for Childhood Stunting in 137 Developing Countries: A Comparative Risk Assessment Analysis at Global, Regional, and Country Levels. PLoS Medicine, 13(11), 1-18. https://doi.org/10.1371/journal.pm ed.1002164

de Onis, M., \& Branca, F. (2016). Childhood stunting: A global perspective. Maternal and Child Nutrition, $\quad 12, \quad 12-26$. https://doi.org/10.1111/mcn.1223 1

Dewey, K. G. (2016). Reducing stunting by improving maternal, infant and young child nutrition in regions such as South Asia: Evidence, challenges and opportunities. Maternal and Child Nutrition, 12, 27-38.

https://doi.org/10.1111/mcn.1228 2

Fajriani, F., Aritonang, E. Y., \& Nasution, Z. (2020). Hubungan Pengetahuan, Sikap dan Tindakan Gizi Seimbang Keluarga dengan Status Gizi Anak Balita Usia 2-5 Tahun. Jurnal Ilmu Kesehatan Masyarakat, 9(01), 1-11. https://doi.org/10.33221/jikm.v9i0 
1.470

Ika, L., \& Ariati, P. (2019). FaktorFaktor Resiko Penyebab Terjadinya Stunting Pada Balita Usia 23-59 Bulan Risk Factors Causes Of Stunting In Toddlers Aged 23-59 Months. Jurnal Oksitosn Kebidanan, VI(1), 28-37.

Kusumawati, E., Rahardjo, S., \& Sari, H. P. (2013). Model Pengendalian Faktor Risiko Stunting pada Anak Usia di Bawah Tiga Tahun. Jurnal Kesehatan Masyarakat, 9(3), 249256.

Mugianti, S., Mulyadi, A., Anam, A. K., \& Najah, Z. L. (2018). Faktor penyebab anak stunting usia 25-60 Bulan di Kecamatan Sukorejo Kota Blitar. Jurnal Ners Dan Kebidanan (Journal of Ners and Midwifery), 5(3), 268-278. https://doi.org/10.26699/jnk.v5i3. art.p268-278

Parisudha, A., Miftakhul, R., Gizi, D., \& Masyarakat, K. (2020). PENINGKATAN

PENGETAHUAN MENGENAI 1.000 HPK UNTUK MENCEGAH RISIKO STUNTING PADA KADER AISYIYAH BANGUNTAPAN UTARA Improvement of Knowledge about First 1000 Days of Life and Stunting Risk on Aisyiyah North Banguntapan Branch. Jurnal Kesehatan Global, 3(2), 62-68.

Roediger, R., Taylor Hendrixson, D., \& Manary, M. J. (2020). A roadmap to reduce stunting. American Journal of Clinical Nutrition, 112, 773S-776S. https://doi.org/10.1093/ajen/nqaa2 05

Sari, D. F., \& Oktacia, R. (2018). Gambaran Faktor Risiko Kejadian Stunting Pada Balita Di Wilayah Kerja Puskesmas Nangalo Kota Padang. Jurnal Kesehatan Mercusuar, 1(1). https://doi.org/10.36984/jkm.v1i1. 10

Sewa, R., Tumurang, M., Boky, H., Kesehatan, F., Universitas, M., Ratulangi, S., \& Stunting, T. P. (2019). Pengaruh Promosi Kesehatan Terhadap Pengetahuan Dan Sikap Dengan Tindakan Pencegahan Stunting Oleh Kader Posyandu Di Wilayah Kerja Puskesmas Bailang Kota Manado. Kesmas, 8(4), 80-88.

Wulandari, H. W., \& Kusumastuti, I. (2020). Pengaruh Peran Bidan, Peran Kader, Dukungan Keluarga dan Motivasi Ibu terhadap Perilaku Ibu dalam Pencegahan Stunting pada Balitanya. Jurnal Ilmiah Kesehatan, 19(02), 73-80. https://doi.org/10.33221/jikes.v19i 02.548

Yuliani, E., Haerianti, M., Nurpadila, Immawanti, Irfan, \& Yunding, J. (2018). Pelatihan Kader Kesehatan Deteksi Dini Stunting Pada Balita Di Desa Betteng ( Health Cadre Training About Early Detection Of Stunting Toddler In Betteng Village). Jurnal Kesehatan Masyarakat, 01, 41-46.

Zuraida, R., Apriliana, E., Wijaya, S. M., Ayu, N., \& Irawati, V. (2017). Peningkatan Pengetahuan Kader Posyandu tentang Buku KIA 
DOI: https://doi.org/10.21009/sarwahita.191.18

P-ISSN: 0216-7484

E-ISSN: 2597-8926

$\begin{array}{lrr}\text { dalam } & \text { Rangka } & \text { Pencegahan } \\ \text { Stunting } & \text { pada } & \text { Komunitas }\end{array}$

Agromedicine Desa Karang Anyar

Kecamatan Jati Agung Kabupaten

Lampung Selatan. Jurnal

Pengabdian Masyarakat Ruwa

Jurai, 54-57. 